\title{
MATERNAL CARE IN THE NEOTROPICAL HARVESTMAN BOURGUYIA ALBIORNATA (ARACHNIDA: OPILIONES): OVIPOSITION SITE SELECTION AND EGG PROTECTION
}

by

\author{
GLAUCO MACHADO and PAULO S. OLIVEIRA ${ }^{1,2)}$ \\ (Departamento de Zoologia, Universidade Estadual de Campinas, CP 6109, 13083-970 \\ Campinas SP, Brazil)
}

(Acc. 29-X-2002)

\section{Summary}

Females of the harvestman Bourguyia albiornata oviposit almost exclusively inside the tube formed by the curled leaves of the bromeliad Aechmea nudicaulis. Oviposition is not correlated with rainfall or with temperature, but is negatively correlated with the number of individuals of A. nudicaulis emitting flowers. Because the inflorescence stalk occupies the tube of leaves of flowering bromeliads, oviposition site is not available for ovigerous females. During one year, $83.6 \%$ of the females produced only one egg-batch and the remaining produced two or three batches. The mean number of eggs per batch along successive reproductive events decreased significantly. A field experiment in which females were removed from the nest bromeliad showed that less than $7 \%$ of the unprotected eggs survived beyond two weeks. In a control in which females were maintained over the eggs, predators attacked only one egg-batch. Ants were the most important egg predators, and at the study site at least 20 species nest and/or forage in A. nudicaulis. Intense predation on eggs by generalist predators may be an important pressure promoting parental care in Neotropical harvestmen.

1) E-mail address: glaucom@unicamp.brand pso@unicamp.br

2) We are very grateful to the staff of the Parque Estadual da Ilha do Cardoso for logistical support. Taxonomic identifications were provided by R. Pinto-da-Rocha (harvestman), A.D. Brescovit and A.J. Santos (spiders), and C.R.F. Brandão and R. Cogni (ants). We also thank M. Sazima for the photo of the bromeliad, and several friends for help in the field. A.A. Giaretta, P. Gnaspini, R. Macías-Ordóñez, and an anonymous reviewer provided helpful comments that greatly improved the manuscript. The study was supported by fellowships from the Conselho Nacional de Desenvolvimento Científico e Tecnológico (CNPq), and the Fundação de Amparo à Pesquisa do Estado de São Paulo (FAPESP). 


\section{Introduction}

In subsocial species, adults increase offspring survival by protecting the brood against biotic and abiotic factors (Wilson, 1971). The protective activities, however, also cost time and energy and may reduce the parent's capacity to produce additional progeny (Trivers, 1972). In groups where parental care is widespread, researchers have focused on how much care is provided by the parents. In other groups where parental care appears occasionally, the main question is why this behaviour has evolved among some species and not others (Wilson, 1971, 1975; Tallamy \& Wood, 1986).

Parental care of eggs is uncommon among arthropods, occurring in nearly twenty orders (Zeh \& Smith, 1985). This behaviour, however, is present in all arachnid orders, except for the Palpigradi whose reproductive behaviour is unknown (Weygoldt, 1969, 1972, 2000; Pittard \& Mitchell, 1972; Brach, 1975; Foelix, 1982; Polis, 1990; Punzo, 1998; Machado \& Raimundo, 2001). Particularly in the order Opiliones, there is a wide diversity of forms of parental activities, varying in complexity and duration and ranging from egg burying to long associations between the parent and the offspring (review in Machado \& Raimundo, 2001). Parental care has been recorded for more than 30 harvestmen species in at least seven not-closely related families, suggesting that this behaviour probably evolved independently among different lineages (Machado \& Raimundo, 2001). All subsocial harvestmen belong to the suborder Laniatores, and most occur in tropical regions. The great majority of reports on harvestmen breeding behaviour, however, is anecdotal or based on observations in laboratory conditions, and do not provide data on reproductive seasonality and natural enemies of the brood. Therefore, such studies offer little information on the environmental conditions in which subsocial behaviour may be adaptive.

The relevance of parental care has been experimentally assessed only for two harvestmen species: Zygopachylus albomarginis, the first arachnid known to exhibit paternal care (Mora, 1990), and Goniosoma longipes, whose females reproduce inside caves (Machado \& Oliveira, 1998). In both cases the parental individual has a crucial protective role, and actively defends the brood against predators such as ants and/or conspecifics. Additionally, males of $Z$. albomarginis are able to prevent fungal attack to eggs, a fact not observed in $G$. longipes. Despite the importance of these examples, more studies on the role of parental care in harvestmen are needed to un- 
derstand their adaptive meaning in different environments, and to construct hypotheses on the evolution of subsocial behaviour in the Opiliones.

The Gonyleptidae is the richest harvestman family and possesses a strictly Neotropical distribution (Shear, 1982). Species in the subfamily Bourguyiinae, a basal group within the family Gonyleptidae, are endemic to the Brazilian Atlantic Rainforest (Kury, 1994). Bourguyia albiornata is a large-bodied harvestman $(7 \mathrm{~mm})$ frequently found on vegetation. Females of B. albiornata lay eggs on epiphytic bromeliads and take care of eggs and nymphs. In this paper we provide a field account of the reproductive effort and subsocial behaviour of this harvestman species. We first investigate the selection of bromeliads for oviposition, as well as the phenological relationship between the harvestman and the preferred nest plant. In the second part of the study we experimentally assess the role of maternal care against predation. The following questions were addressed: (i) where and when do females lay their eggs? (ii) what are the main sources of egg mortality? (iii) does maternal care in B. albiornata reduce brood mortality due to predation?

\section{Study area}

The study was carried out at Cardoso Island $\left(25^{\circ} 03^{\prime} \mathrm{S} ; 47^{\circ} 53^{\prime} \mathrm{W}\right)$, South coast of São Paulo State, Southeast Brazil. The climate is generally warm and wet throughout the year but may be divided into two seasons. The cold season lasts from June to September and is characterised by less frequent rainfall $(\mathrm{ca} 500 \mathrm{~mm})$ and mean temperature of $17.4^{\circ} \mathrm{C}$. From October to May there is a warm season when rainfall is abundant $(1800 \mathrm{~mm})$ and the mean temperature is $25.5^{\circ} \mathrm{C}$ (Funari et al., 1987). The vegetation in the area is mainly a sandy coastal forest (locally called 'restinga' forest), which is part of the Atlantic forest domain and frequently adjoins coastal rainforests (Oliveira-Filho \& Fontes, 2000). The sandy forest grows on poor sandy soils (2-3 m alt.) being constituted by small trees $(6 \mathrm{~m}$ high) and an understory dominated by terrestrial bromeliads, herbs, and a few shrubs (Barros et al., 1991).

\section{Methods}

\section{Naturalistic observations}

Field observations were conducted at 15-25 day intervals from January to December 2000. All epiphytic bromeliads found in the forest along a 1-km transect ( $1 \mathrm{~m}$ wide) were inspected for ovipositions of Bourguyia albiornata. The censuses were generally conducted between 08:00 and 15:00 h. Selection for oviposition site by B. albiornata was evaluated by comparing the frequency of bromeliads containing egg-batches with the quantitative survey of all epiphytic bromeliads previously conducted by Camargo (2002) along the same transect. 
Behavioural data on harvestmen are based on 53 days of fieldwork and more than $300 \mathrm{~h}$ of naturalistic observations, of which nearly $40 \mathrm{~h}$ comprised nocturnal observations from 18:00 to 01:00 h. All egg-guarding females were marked on the dorsum with coloured dots of enamel paint (Testors, Rockford Co., USA), and the number of eggs was counted. This procedure apparently did not affect the females' behaviour (see also Machado \& Oliveira, 1998). The nest bromeliad was also marked with the corresponding colour dot of the guarding female. The number of eggs per batch in successive oviposition events, and the interval between these ovipositions were compared using an analysis of variance (ANOVA) and a $t$-test, respectively.

Continuous recording (up to $30 \mathrm{~min}$ ) was made of all relevant behavioural events (see Martin \& Bateson, 1986), such as interactions between guarding females and other animals, and attacks of egg predators. Voucher specimens were deposited in the arachnological collection of the Museu de Zoologia da Universidade de São Paulo (MZSP), Brazil.

\section{Field experiment: the role of maternal care}

The protective role of maternal care against egg predation was evaluated through a field experiment in March 2001. Two experimental groups of 10 egg-batches each were randomly designated by the flip of a coin as treatment or control. In the treatment group guarding females were removed from the nest bromeliads and the eggs were left unattended (mean \pm $\mathrm{SD}=131.4 \pm 25.8$ eggs/batch). In the control group guarding females were removed from the nest bromeliads and placed again in the same location after $5 \mathrm{~min}(123.5 \pm 20.2 \mathrm{eggs} / \mathrm{batch})$. There was no significant difference in the initial number of eggs per batch between the two groups ( $t$-test: $t=0.763, p=0.455)$. All experimental egg-batches were on bromeliads of similar size and height (1-1.5 m above the ground), at least $5 \mathrm{~m}$ apart, and at initial developmental stage (determined by egg size and colouration). Over 14 days, the batches of both experimental groups were checked at least three times a day (generally at 10:00, 14:00 and 20:00 h) to identify egg predators. A repeated-measures ANOVA was performed on the number of eggs per batch before (day 1) and after (day 14) treatment. Additional data on egg predators were also gathered from six egg-batches whose females were experimentally removed during a $24 \mathrm{~h}$-period in a preliminary phase of this study, and from 11 egg-batches whose females had deserted.

Ants were the most important egg predators (see below). To evaluate ant abundance and the composition of species that nest and/or forage on vegetation, 100 tuna baits were distributed on the vegetation (5-10 m apart) along a $1 \mathrm{~km}$-transect. Baits were placed on leaves of the bromeliad Aechmea nudicaulis (the preferred oviposition site) at $08: 00 \mathrm{~h}$ and were checked twice within a 3h-period. Ant workers attending the baits were counted and collected for identification.

\section{Results}

\section{Oviposition site}

Females of Bourguyia albiornata used almost exclusively the bromeliad Aechmea nudicaulis (Fig. 1a) as oviposition site $(N=281)$. Only once an- 


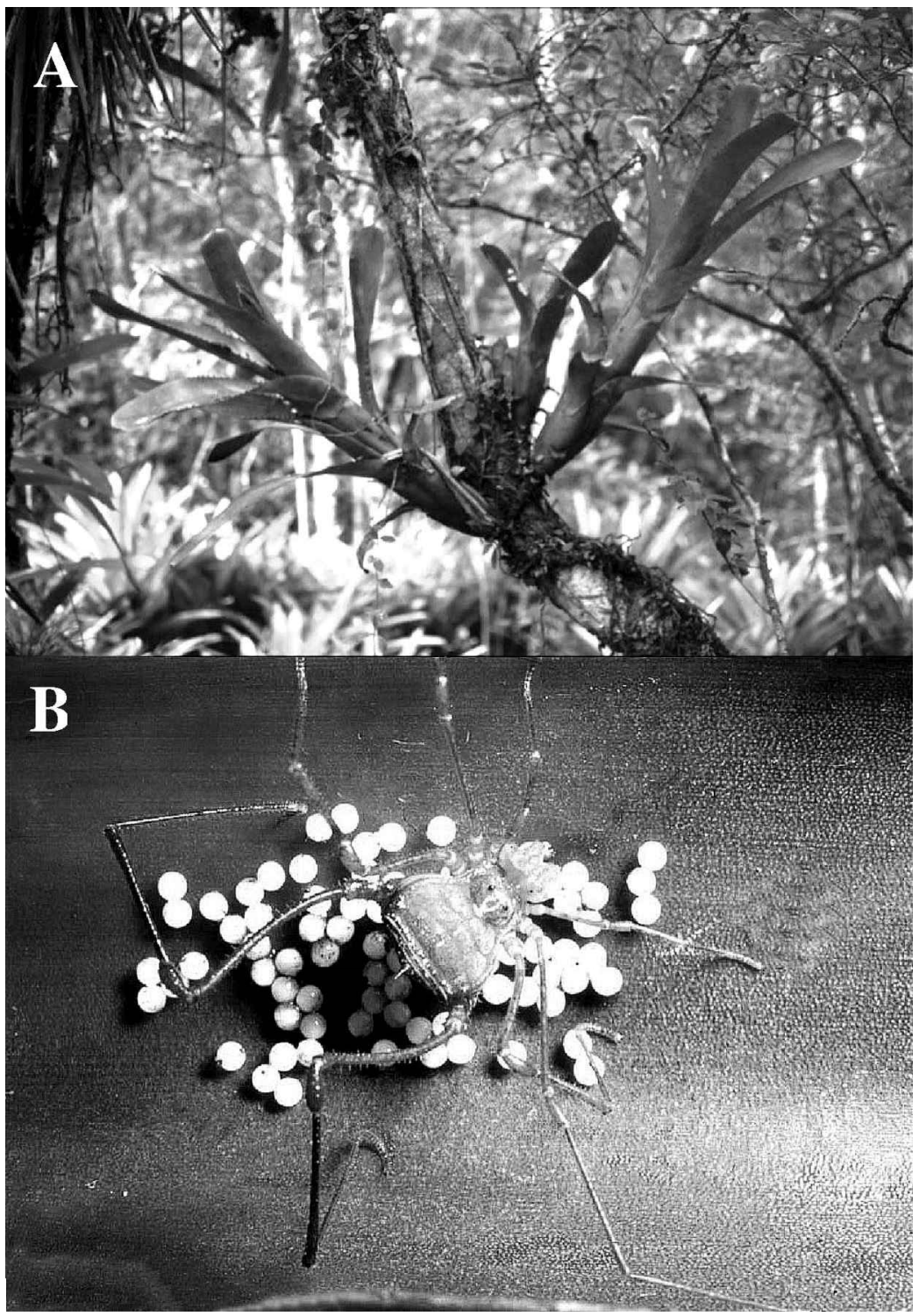

Fig. 1. (A) A small clump of the epiphytic bromeliad Aechmea nudicaulis at Cardoso Island, SE Brazil. The curled leaves form a tube that accumulates water, and that is used as oviposition site by the harvestman Bourguyia albiornata. (B) Female of B. albiornata (body size $=7 \mathrm{~mm}$ ) guarding her eggs inside the bromeliad. 
other bromeliad species, Aechmea sp., was found being used by B. albiornata. Aechmea species have curled leaves forming a tube (up to $50 \mathrm{~cm}$ long) that accumulates water and also confers protection from sunlight (Fig. 1a).

The great majority of the nest bromeliads contained only one egg-batch $(N=275)$, but in a few cases the same leaf tube hosted two ovipositions $(N=7)$. In these cases, no agonistic interactions were observed between the egg-guarding females. On 25 different occasions one adult male was found close $(2-5 \mathrm{~cm})$ to a guarding female. Such males remained inside the nest bromeliads for up to 4 days and occasionally touched the guarding females with the second pair of legs. On three occasions males were observed successfully copulating with guarding females, but on two other cases the latter attacked and repelled the males from the nest bromeliad.

\section{Reproductive seasonality}

A total of 189 egg-batches of B. albiornata were found during 2000. Reproductive activity occurred between February and October, being more intense from March to May (Fig. 2a). The number of egg-batches per month was not correlated with rainfall $\left(r_{\mathrm{s}}=-0.159 ; N=12 ; p=0.68\right)$ or temperature $\left(r_{\mathrm{s}}=-0.555 ; N=12 ; p=0.07\right)$. However, the percentage of individuals of $A$. nudicaulis used as breeding site by females of $B$. albiornata was negatively correlated with the percentage of flowering individuals of this bromeliad ( $\left.r_{\mathrm{s}}=-0.751 ; N=12 ; p<0.01\right)$ (Fig. $2 \mathrm{~b}$ ).

During one year of monthly records along the $1 \mathrm{~km}$-transect, $83.6 \%$ of the females produced only one egg-batch, $14.3 \%$ produced two, and only $2.1 \%$ oviposited three times. The mean number of eggs per batch along successive reproductive events was significantly different (ANOVA: $F=8.842$; $p<0.001)$. Females laid more eggs in the first oviposition than in the second and third reproductive events (Fig. 3). The mean time interval between the first and second ovipositions was 83.6 days $(\mathrm{SD}=39.5$; range $=28$ 171 days; $N=27$ ), and between the second and third was 72.3 days $(\mathrm{SD}=47.5$ days; range $=33-129$ days; $N=4)$. These intervals were not significantly different ( $t$-test: $t=0.525 ; p=0.603$ ).

\section{Reproductive effort and parental care}

All observed egg-batches $(N=282)$ were guarded by one adult female, either sitting on the eggs or remaining next to the batch (Fig. 1b). The 

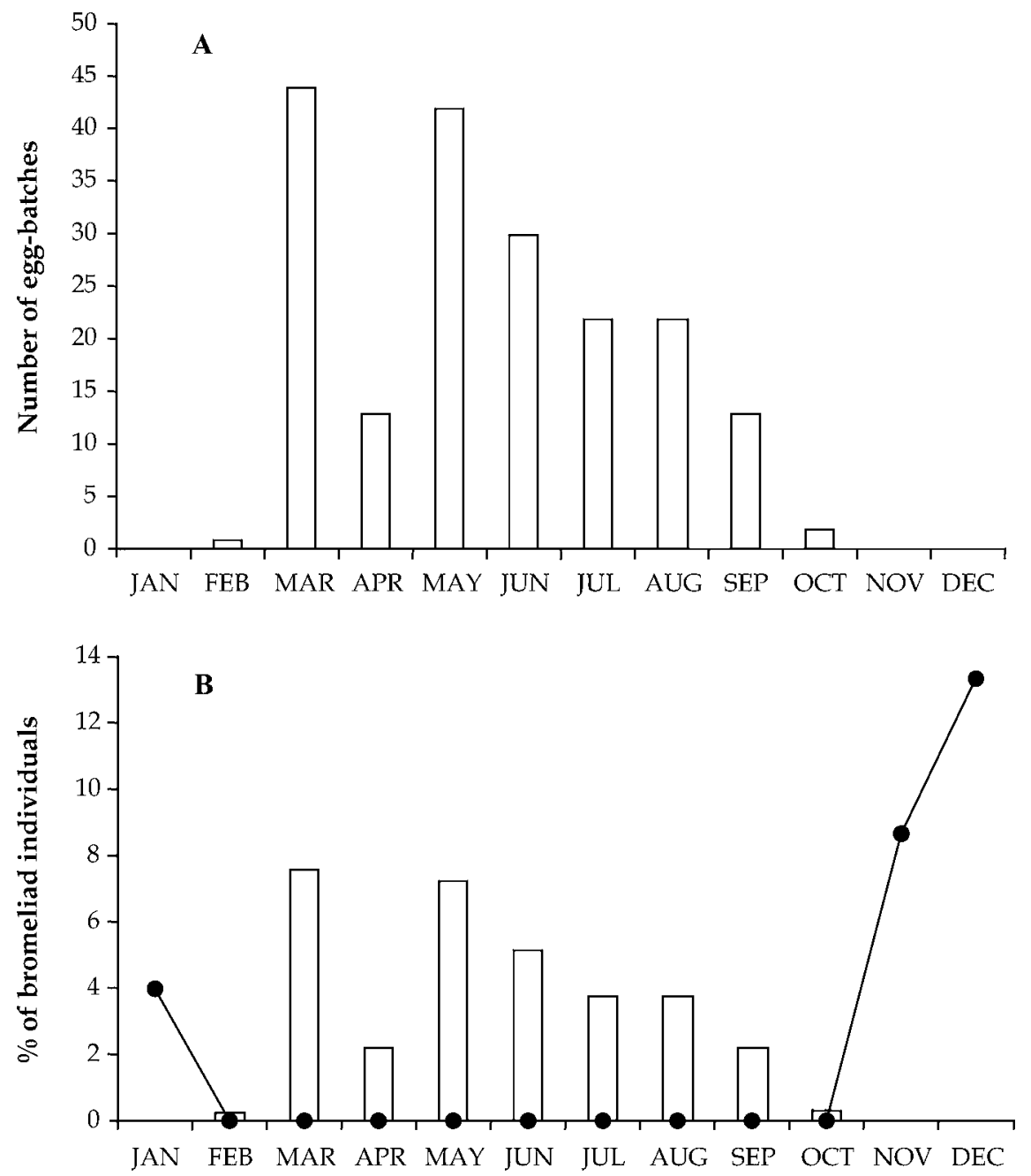

Months

Fig. 2. (A) Number of egg-batches of the harvestman Bourguyia albiornata observed monthly from January to December 2000 at Cardoso Island, SE Brazil. (B) Percentage of individuals of the bromeliad Aechmea nudicaulis used as oviposition site by the harvestman B. albiornata (bars), and percentage of individuals with flowers (line).

guarding female frequently touched the eggs with the first and second pairs of legs, and also inspected the periphery of the egg-batch. This activity sometimes lasted up to $30 \mathrm{~min}$. As opposed to non-reproductive individuals, 


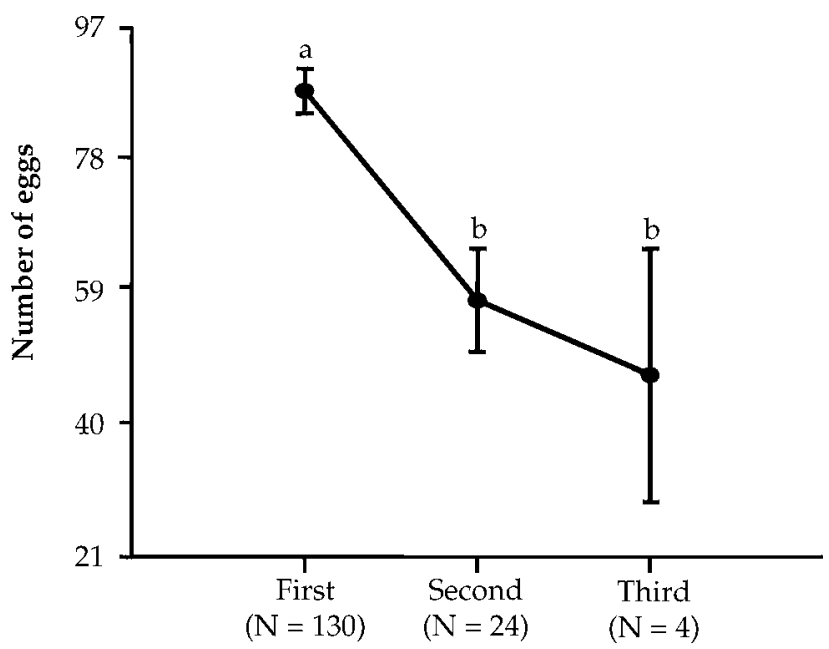

Reproductive events

Fig. 3. Mean number of eggs laid by females of the harvestman Bourguyia albiornata along successive reproductive events. Different letters indicate significant difference (Tukey test). Bars $=\mathrm{SD}$ and $N=$ number of egg-batches in each category.

guarding females of $B$. albiornata were never observed leaving the nest bromeliad to forage at night.

Eggs were spaced out by 1-2 mm within the batch, laid in a single layer, and were covered by a thin mucus (Fig. 1b). As in other laniatorean harvestmen (Gnaspini, 1995; Machado \& Oliveira, 1998), eggs of B. albiornata become darker and increase in volume during the embryonic development. Recently laid eggs have a cream colouration and average $1.19 \pm 0.10 \mathrm{~mm}$ in diameter $(N=20$ eggs). Just before hatching the eggs are dark in colour and mean egg diameter is $1.34 \pm 0.07 \mathrm{~mm}(N=20$ eggs $)$.

The hatching of all nymphs within a clutch was asynchronous and lasted up to eight days between the emergence of the first and the last nymphs (range 1-8 days; $N=15$ ). The mean time of embryonic development was 35.2 days $(\mathrm{SD}=2.1$ days; range $=30-39$ days; $N=19$ ). After hatching, the nymphs remained aggregated under the guarding female for up to six days before dispersal. The total period of maternal care towards eggs and nymphs lasted 35-43 days. The guarding females were only observed to leave the oviposition site after all 1st-instar nymphs had dispersed.

Females of $B$. albiornata actively defended their offspring against other organisms that entered the bromeliads. On one occasion a female was seen 


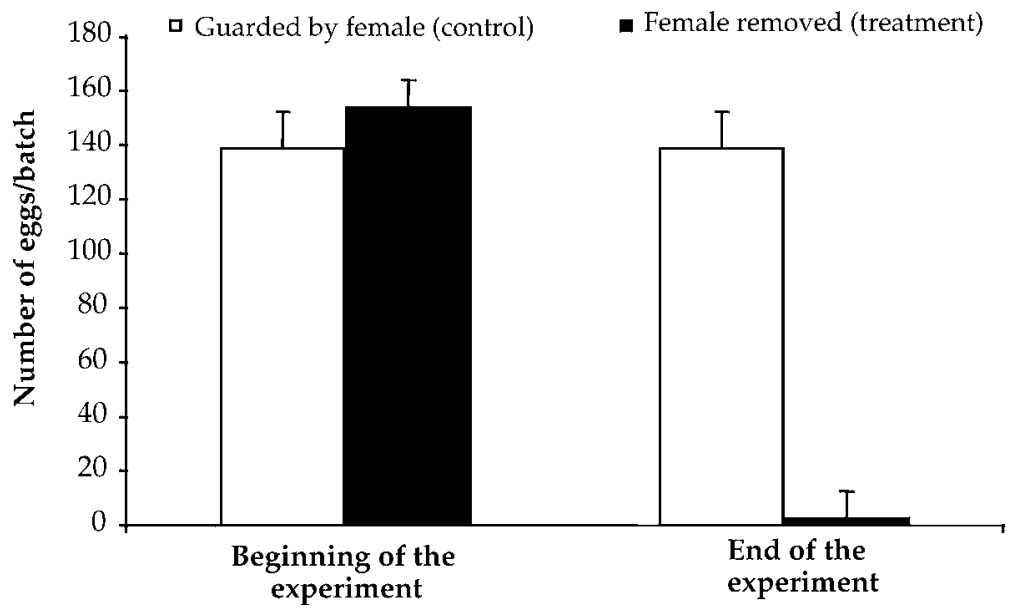

Fig. 4. Effect of maternal care on egg survival in the harvestman Bourguyia albiornata after two weeks (mean and SE).

repelling from the nest bromeliad a katydid (Ensifera: Tettigoniidae) twice her size. Two other females were each observed fighting with conspecifics (one juvenile and one adult male), and in both cases they expelled the intruder from the bromeliad. When not brooding eggs, however, females were very tolerant to conspecifics and were found in small aggregations (up to 12 individuals), including adults (males and females) and juveniles, inside the tube of leaves of $A$. nudicaulis.

Although the focus of this study was the guarding females, more than 400 non-reproductive individuals of $B$. albiornata (including adults and juveniles) were seen sheltered inside the tube of leaves of A. nudicaulis. Observed predation events involved three guarding females and had the following large spiders as predators: Phoneutria nigriventer, Ctenus sp., and another unidentified species.

\section{Effects of maternal care on egg survival}

The results of the field experiment unequivocally showed that guarding females have a protective role and a positive effect on egg survival (repeated measures ANOVA: $\left.F_{1,18}=26.18 ; p<0.001\right)$. Predators attacked all eggbatches in the treatment group, with less than $7 \%$ of the unguarded eggs surviving the 2-week experiment (Fig. 4). In the control group, however, only one egg-batch was attacked and entirely consumed. In this case, the 
leaf tube previously containing the female and her eggs was taken over by a colony of Crematogaster ants (Myrmicinae). It was not possible to know if the guarding female was expelled from the nest bromeliad by the ants, or if she was preyed on before or during ant invasion.

The main source of mortality for unprotected egg-batches was ants, but cannibalism was also recorded. Five ant species were seen eating eggs of B. albiornata in the field: Gnamptogenys moelleri ( $N=4$ batches), Pachycondyla villosa $(N=2)$, Crematogaster sp. $(N=1)$, Pheidole sp. $(N=2)$, and Dolichoderus attelaboides $(N=1)$. Predation of entire eggbatches by recruited ants usually began about $5 \mathrm{~h}$ after female removal.

The sampling with tuna baits revealed that $73 \%$ of the individuals of A. nudicaulis $(N=100)$ were occupied by ant nests and/or within the foraging ranges of ant colonies. Twenty ant species were found attending tuna baits on the bromeliads, and the most common species were Crematogaster sp. (17.5\%), G. moelleri (14.4\%), Pheidole sp. (13.4\%), and D. attelaboides $(12.4 \%)$. Another potential predator that is very abundant at the study site is the army ant Eciton burchelli. This ant species forages both on ground and on vegetation and was occasionally seen entering the leaf tube of $A$. nudicaulis.

Both males $(N=2)$ and females $(N=1)$ of $B$. albiornata were observed consuming unguarded eggs. Cannibalistic harvestmen ate 2-18 eggs per batch and were never observed consuming entire egg-batches. On two different occasions one unidentified cockroach species (Dictyoptera: Blattidae) was found over unprotected egg-batches in which a small fraction of the eggs had disappeared.

Finally, an additional source of egg mortality was fungal attack. Fungi infected two egg-batches out of 282; the number of affected eggs was 2 and 10. Guarding females did not remove or eat the infected eggs.

\section{Discussion}

Choice of nest-site: where and when to lay eggs?

Nest-site selection is one of the most important decisions made by animals that lay eggs. For brood-guarding species, the selected site must present appropriate physical conditions for the development of the eggs as well as for the parental individuals (Morse, 1985; Resetarits, 1996). An inadequate place may subject both the offspring and the parents to a wide range of 
unfavourable factors such as dehydration, predation, and parasitism (Wilson, 1975; Clutton-Brock, 1991). Many spiders exhibit precise nest-site selection for oviposition (see Morse, 1985), and this behaviour also seems to be important among harvestmen (Machado \& Raimundo, 2001).

There are more than 15 epiphytic species of bromeliads in the study site (Wanderley \& Mollo, 1992), with Vrisea procera comprising $80 \%$ of all individuals (Camargo, 2002). This bromeliad accumulates some water in the axil of leaves but does not form a tube of leaves, as in A. nudicaulis and Aechmea sp. (Wanderley \& Mollo, 1992). Therefore, V. procera does not seem an appropriate nest site for the reproduction of $B$. albiornata. Females of Bourguyia albiornata oviposit almost exclusively inside the bromeliad Aechmea nudicaulis, despite the fact that this species accounts for only $10 \%$ of all epiphytic bromeliads found in the study site (Camargo, 2002). This indicates that B. albiornata prefers $A$. nudicaulis as oviposition site. This bromeliad, as well as Aechmea sp., accumulates water inside the tube of leaves and provide a suitable microenvironment for the offspring, such as protection from stressful climatic factors and moisture fluctuations (Machado \& Oliveira, in prep.). Although harvestman eggs are known to develop and hatch more successfully when brooded in humid atmosphere (Edgar, 1971; Machado \& Oliveira, 1998), this study is the first to provide quantitative evidence for selection of oviposition site in the group.

In the tropics many species of vertebrates and invertebrates inhabit tank bromeliads, and this is especially common during the dry season when these plants may constitute the only above-ground water reservoir (Neill, 1951). Indeed, some animals are entirely dependent on tank bromeliads for reproduction and larval development (e.g. Diesel \& Schuh, 1993; Bourne et al., 2001). As opposed to what was found for the cave-dwelling harvestman Goniosoma longipes (Machado \& Oliveira, 1998), the number of eggbatches per month of B. albiornata is not correlated with rainfall. Egg development in $B$. albiornata may be less dependent of rainfall because the leaf tube of $A$. nudicaulis accumulates water throughout the year, creating a wet microhabitat inside the nest bromeliad.

The number of egg-batches of $B$. albiornata found in the field peaked just after the flowering period of $A$. nudicaulis. Because the inflorescence stalk occupies the tube of leaves in flowering bromeliads, oviposition sites are not available for ovigerous females. The synchronisation of the maternal investment in offspring with the phenology of A. nudicaulis suggests that the 
reproductive activity of $B$. albiornata may be related to the availability of appropriate oviposition sites.

\section{Costs of maternal care}

The costs of reproduction for parental individuals can be analysed at two levels (Bell, 1976; Rosenheim, 1999). First, the preovipositon cost associated with the allocation of energy to egg production and other parental activities (rather than individual growth or maintenance), as well as with an increased exposure to predation while searching for an appropriate oviposition site. Second, the oviposition and postoviposition costs that include enhanced predation risk while laying eggs and guarding the offspring, decreased foraging ability, and loss of new reproductive opportunities in the case of some subsocial species. The results obtained in this study illustrate the postoviposition costs imposed to a harvestman female. Guarding females of B. albiornata remain over an egg-batch for up to 43 days and during this period they may become more vulnerable to predators. Although the nest bromeliad provides an effective refuge against large predators (mainly birds and mammals), it also represents a dead end tube if a predator, such as a spider, enters the bromeliad and attacks the female.

From a physiological standpoint, females first invest a great amount of energy to produce large and nutritionally rich eggs. Additionally, they may spend time and energy searching for a bromeliad to be used as an oviposition site. Besides selecting A. nudicaulis as the nest site for oviposition, females of B. albiornata further choose an array of morphological features among bromeliad individuals such as length and inclination of the leaf tube, and amount of accumulated debris (Machado \& Oliveira, in prep.). Therefore, it is reasonable to suppose that females invest some time and energy looking for an appropriate nest bromeliad. Finally, maternal care prevents foraging activities by females and reduces the intake of energy to produce additional eggs - what is particularly important for iteroparous species (Tallamy \& Brown, 1999). In fact, the few females of B. albiornata that reproduced more than once presented decreased fecundity in subsequent reproductive events, suggesting a trade-off between egg production and maternal care (Tallamy $\&$ Denno, 1982). The great majority of females, however, were constrained to a single reproductive event.

We suggest that females of B. albiornata are opportunistically iteroparous and that constraints such as availability of food and/or nest sites make 
this species functionally semelparous (see Tallamy \& Brown, 1999). If environmental or phylogenetic constraints reduce the success of subsequent reproductive events during a breeding season, the fecundity-related costs of maternal care are minimised, even if the female lives to produce another batch in the following breeding season (e.g. Kight, 1997; Eggert \& Müller, 1997). Females constrained to produce only one batch in a given breeding season could increase their reproductive success (in terms of offspring survival) by guarding the eggs that they have already laid. This is particularly true in environments where predation on eggs and juveniles is high and female protection may effectively reduce offspring mortality (see below).

\section{Role of maternal care}

Intense predation on eggs and juveniles by a number of generalist predators may select for parental care if the risks to the parent do not override the benefits to the offspring in terms of survival (Wilson, 1971; Tallamy \& Denno, 1981). Our field experiment demonstrated that maternal care in B. albiornata has a crucial protective role preventing egg predation. Unprotected eggs are promptly attacked by ants, which may consume an entire batch in a few hours. The effectiveness of the maternal care in harvestmen was previously shown for Goniosoma longipes, whose females reproduce inside caves (Machado \& Oliveira, 1998). In the cavernicolous environment, however, the most important predators are conspecific individuals that are capable of cannibalising entire egg batches (Machado \& Oliveira, 1998). The difference in the nature of predation pressures between Goniosoma and Bourguyia is probably related with the low frequency of ants inside caves, the common habitat of Goniosoma (see also Machado et al., 2000). In the external environment ants are by far the most important predator group (Wilson, 1975; Hölldobler \& Wilson, 1990), and at our study site at least 20 species nest and/or forage in the same bromeliad used by females of B. albiornata as oviposition site. Females of the green lynx spider, Peucetia viridans, oviposit on vegetation and field experiments demonstrated that only $9 \%$ of the unprotected eggs sacs hatched successfully (Fink, 1986). As shown for B. albiornata, egg-guarding by Peucetia females significantly reduced brood mortality due to ant predation on foliage (Fink, 1986).

Tallamy \& Schaefer (1997) proposed that subsociality in arthropods would be a plesiomorphic behavioural feature, and that the derived state is 
represented by more efficient and less costly reproductive methods, such as piercing ovipositors and precocial eggs (see also Tallamy \& Brown, 1999). In fact, this pattern seems to be common in some subsocial arthropod groups such as hemipterans (Tallamy \& Schaefer, 1997). Among harvestmen, however, subsociality evolved independently several times from a plesiomorphic state of egg-burying, or egg-hiding (Machado \& Raimundo, 2001). In the Neotropical family Gonyleptidae it is not clear if maternal care is primitive or has risen repeatedly in different species. Although there is no information on reproductive biology for some basal subfamilies of Gonyleptidae, Machado \& Raimundo (2001) suggested that subsociality in the group is derived rather than ancestral. Comparative studies on a wider set of species are needed to better understand the evolution of subsocial behaviour in the family, and to assess the advantages and disadvantages of the various forms of care in harvestmen.

\section{References}

Barros, F., Melo, M.M.R.F., Chiiea, S.A.C., Kirizawa, M., Wanderley, M.G.L. \& JungMendaçolli, S.L. (1991). Flora fanerogâmica da Ilha do Cardoso. Caracterização geral da vegetação e listagem das espécies ocorrentes. — Indústrias de Papel Simão S.A., São Paulo.

Bell, G. (1976). On breeding more than once. - Am. Nat. 110, p. 57-77.

Bourne, G.R., Collins, A.C., Holder, A.M. \& McCarthy, C.L. (2001). Vocal communication and reproductive behavior of the frog Colostethus beebei in Guyana. - J. Herpetol. 35, p. 272-281.

Brach, V. (1975). Development of the whipscorpion Schizomus floridanus, with notes on behaviour and laboratory culture. - Bull. South Californian Acad. 74, p. 97-100.

Camargo, R.X. (2002). Ecologia e comportamento social da formiga arborícola Odontomachus hastatus (Hymenoptera: Formicidae: Ponerinae). — Unpubl. Msc thesis, Universidade Estadual de Campinas, São Paulo, Brazil.

Clutton-Brock, T.H. (1991). The evolution of parental care. - Princeton Univ. Press, Princeton.

Diesel, R. \& Schuh, M. (1993). Maternal-care in the bromeliad crab Metopaulias depressus (Decapoda): maintaining oxygen, $\mathrm{pH}$ and calcium levels optimal for the larvae. Behav. Ecol. Sociobiol. 32, p. 11-15.

Edgar, A.L. (1971). Studies on the biology and ecology of Michigan Phalangida (Opiliones). — Misc. Pub. Mus. Zool. Univ. Mich. 144, p. 1-64.

Eggert, A.K. \& Müller, J.K. (1997). Biparental care and social evolution in burying beetles: lessons from the larder. - In: The evolution of social behaviour in insects and arachnids (J.C. Choe \& B.J. Crespi, eds). Cambridge Univ. Press, Cambridge, p. 216-236.

Fink, L.S. (1986). Costs and benefits of maternal behaviour in the green lynx spider (Oxyopidae, Peucetia viridans). - Anim. Behav. 34, p. 1051-1060. 
Foelix, R.F. (1982). Biology of spiders. - Harvard Univ. Press, Cambridge.

Funari, F.L., Vuono, S.Y. \& Salum, S.T. (1987). Balanço hídrico de duas áreas de Mata Atlântica: Reserva Biológica de Paranapiacaba e Parque Estadual da Ilha do Cardoso (Estado de São Paulo). — In: Anais do Congresso da Sociedade Botânica de São Paulo (M.F.A. Pereira \& M.A.S. Massei, eds). Sociedade Brasileira de Botânica, Campinas, p. $95-101$.

Gnaspini, P. (1995). Reproduction and postembryonic development of Goniosoma spelaeum, a cavernicolous harvestman from southeastern Brazil (Arachnida: Opiliones: Gonyleptidae). - Invertebr. Reprod. Dev. 28, p. 137-151.

Hölldobler, B. \& Wilson, E.O. (1990). The ants. - Harvard Univ. Press, Cambridge.

Kight, S.L. (1997). Factors influencing maternal behaviour a burrower bug, Sehiurus cinctus (Heteroptera: Cydnidae). — Anim. Behav. 53, p. 105-112.

Kury, A.B. (1994). Early lineages of Gonyleptidae (Arachnida: Opiliones: Laniatores). Trop. Zool. 7, p. 343-353.

Machado, G. \& Oliveira, P.S. (1998). Reproductive biology of the Neotropical harvestman Goniosoma longipes (Arachnida: Opiliones: Gonyleptidae): mating and oviposition behaviour, brood mortality, and parental care. - J. Zool. 246, p. 359-367.

- — \& Raimundo, R.L.G. (2001). Parental investment and the evolution of subsocial behaviour in harvestmen (Arachnida: Opiliones). - Ethol. Ecol. Evol. 13, p. 133-150.

— - , — — \& Oliveira, P.S. (2000). Daily activity schedule, gregariousness, and defensive behaviour in the Neotropical harvestman Goniosoma longipes (Arachnida: Opiliones: Gonyleptidae). - J. Nat. Hist. 34, p. 587-596.

Martin, P. \& Bateson, P. (1986). Measuring behaviour: an introductory guide. — Cambridge Univ. Press, New York.

Mora, G. (1990). Parental care in a Neotropical harvestman, Zygopachylus albomarginis (Arachnida: Gonyleptidae). - Anim. Behav. 39, p. 582-593.

Morse, D.H. (1985). Nests and nest-site selection of the crab spider Misumena vatia (Araneae: Thomisidae) on milkweed. - J. Arachnol. 13, p. 383-390.

Neill, W.T. (1951). A bromeliad herpetofauna in Florida. — Ecology 32, p. 140-143.

Oliveira-Filho, A.T. \& Fontes, M.A.L. (2000). Patterns of floristic differentiation among Atlantic Forests in southeastern Brazil and the influence of climate. - Biotropica 32b, p. 793-810.

Pittard, K. \& Mitchell, R.W. (1972). Comparative morphology of the life stages of Cryptocellus pelaezi (Arachnida: Ricinulei). — Grad. Stud. Texas Tech. Univ. 1, p. 1-77.

Polis, G.A. (1990). Ecology. — In: The biology of scorpions (G.A. Polis, ed.). Stanford Univ. Press, Stanford, p. 247-293.

Punzo, F. (1998). The biology of camel spiders. - Kluwer Academic Publishers, The Netherlands.

Resetarits, W.J. (1996). Oviposition site choice and life history evolution. - Am. Zool. 36, p. 205-215.

Rosenheim, J.A. (1999). The relative contributions of time and eggs to the cost of reproduction. - Evolution 53, p. 376-385.

Shear, W.A. (1982). Opiliones. - In: Synopsis and classification of living organisms (S.P. Parker, ed.). New York, McGraw-Hill.

Tallamy, D.W. \& Brown, W.P. (1999). Semelparity and the evolution of maternal care in insects. - Anim. Behav. 57, p. 727-730. 
— — \& Denno, R.F. (1981). Maternal care in Gargaphia solani (Hemiptera: Tingidae). — Anim. Behav. 29, p. 771-778.

— — \& — - (1982). Life history trade-offs in Gargaphia solani (Hemiptera: Tingidae): the cost of reproduction. - Ecology 63, p. 616-620.

— — \& Schaefer, C. (1997). Maternal care in the Hemiptera: ancestry, alternatives, and current adaptative value. - In: The evolution of social behaviour in insects and arachnids (J.C. Choe \& B.J. Crespi, eds). Cambridge Univ. Press, Cambridge, p. 94115 .

— — \& Wood, T.K. (1986). Convergence patterns in subsocial insects. — Ann. Ver. Entomol. 31, p. 369-390.

Trivers, R.L. (1972). Parental investment and sexual selection. - In: Sexual selection and the descent of man (B. Campbell, ed.). Aldine, Chicago, p. 136-179.

Wanderley, M.G. \& Mollo, L. (1992). Bromeliaceae. - In: Flora fanerogâmica da Ilha do Cardoso (São Paulo, Brasil). Champion Papel e Celulose, São Paulo, vol. 3.

Weygoldt, P. (1969). The biology of pseudoscorpions. - Harvard Univ. Press, Cambridge.

— - (1972). Geisselskorpione und Geisselspinnen(Uropygi und Amblypygi). — Z. Koelner Zoo 3, p. 95-107.

— - (2000). Biology of whip spiders (Chelicerata: Amblypygi): their biology, morphology and systematics. - Apollo Books, Stenstrup.

Wilson, E.O. (1971). The insect societies. - Harvard Univ. Press, Cambridge.

— — (1975). Sociobiology: the new synthesis. — Harvard Univ. Press, Cambridge.

Zeh, D.W. \& Smith, R.L. (1985). Paternal investment by terrestrial arthropods. - Am. Zool. 25, p. 785-805. 